\title{
Gut
}

Leading article

\section{Cancer in Crohn's disease: dispelling the myths}

\author{
'The risk of carcinoma developing in Crohn's disease is well known to be less than that of ulcerative colitis' \\ 'The trouble with people is not that they don't know, but that they know so much that ain't so'2
}

The association of ulcerative colitis with colorectal cancer is an old story, having been described by Burrill Crohn in $1925 .^{3}$ Another 23 years elapsed before the first description of a cancer of the colon complicating 'regional enteritis'. ${ }^{4}$ For nearly the next half century, published works abounded with reports of colorectal cancers in series of patients with Crohn's disease. ${ }^{5-9}$ As the absolute numbers of cancer cases were usually small, however, this association was often shrugged off as statistically insignificant, or at best characterised as increased but still much lower than the risk of cancer in ulcerative colitis. This conventional wisdom seems to have persisted to the present day, even though it clearly 'ain't so'.

In the early 1980s, as we reviewed the experience at The Mount Sinai Hospital, we attempted for the first time to calculate direct comparisons between cancer incidences in Crohn's disease and ulcerative colitis. ${ }^{10} 11$ Having noted a parity between the relative risks of colon cancer in Crohn's colitis and in left sided ulcerative colitis of similar extent, ${ }^{11}$ we speculated that 'when cases of ulcerative and Crohn's colitis of similar anatomic extent are followed for similar durations of time, the two diseases may ultimately prove to have similar increases in risk for colorectal cancer'.12

A landmark study in this issue of $G u t$ has now decisively confirmed that early speculation. ${ }^{13}$ A group of eminent investigators from Birmingham compared the cancer risk in two hospital referred but identically selected cohorts of patients with extensive ulcerative colitis and equally extensive Crohn's disease of the colon. As in the classic 1973 paper by Weedon et al, ${ }^{5}$ the overall risk of colorectal cancer was increased nearly 20 -fold over the general population. Moreover, both the relative risks and the absolute 20 year cumulative incidences of cancer were virtually identical in the ulcerative and Crohn's colitis cohorts. This study therefore conclusively establishes the previously reported 111415 but still under appreciated similarity between the cancer risks in these two diseases.

Three other large population based studies of Crohn's disease have curiously overlooked the tremendously increased cancer risks shown in their own data. Investigators in Minnesota, ${ }^{16}$ Copenhagen, ${ }^{17}$ and Israel ${ }^{18}$ have reported no statistically significant increase in cancer risk among the Crohn's disease patients in their catchment areas. All three sets of authors, however, failed to correct their data for the extremely small subsets of their populations that were actually at risk; namely, those with extensive, longstanding, unresected colonic disease. In every instance, this correction shows an approximately 10-fold increase in relative over that calculated by the authors. In the same vein, Munkholm et al recently concluded that the intestinal cancer risk was 'not found increased' in a regional cohort of 373 Crohn's disease patients in Denmark, ${ }^{19}$ even though the relative risk was 8.3 among unoperated patients with 10 or more years duration $(p<0.005)$. All these papers thus remind us that even the best conducted population based studies are not infallible unless their calculations are based appropriately upon the subpopulations that are truly at risk.

Considerations of fallibility also provide the opportunity to dispel three other myths concerning cancer in Crohn's disease. One is the myth of the bypassed loop. There is a prevalent misconception that cancer in Crohn's disease has a particular predilection for bypassed loops of small and large intestine. To be sure, many of these cancers, including about $40 \%$ of reported small bowel carcinomas, do occur in bypassed loops. ${ }^{20}$ This apparent association, however, is primarily an artefact of the over representation of patients with bypassed loops among the subset of patients who have been carrying unresected segments of Crohn's disease in situ for over 30 or 40 years, when the cancer risk is at its highest. In other words, it is not the bypassed loop in itself that puts the patient at risk for cancer; it is the long duration of unresected disease. ${ }^{12}$ Indeed, the great preponderance of both small and large bowel cancers in Crohn's disease occur in the in-continuity intestine. ${ }^{20}$ On the other hand, cancers arising in bypassed loops contribute disproportionately to the mortality of Crohn's disease associated cancer, ${ }^{21}$ which otherwise would not differ substantially from that of colon cancer either in ulcerative colitis or in the general population. ${ }^{10}$

The second myth is that cancers in Crohn's disease are restricted to areas of grossly affected intestine. In the 
Mount Sinai series, as many as a third of the cancers arose in distant segments of the gastrointestinal tract either far proximal or distal to macroscopically obvious Crohn's disease. ${ }^{10}$ Indeed, several cases in this series, as well as more recent ones, ${ }^{22}$ echo suspicions from the $1960 \mathrm{~s}^{2324}$ of a possible association of colorectal cancer even with Crohn's disease limited to the small bowel.

The third myth pertains to young age at onset of colitis as an independent risk factor for colorectal cancer. As others have observed in ulcerative colitis, ${ }^{25}$ the Birmingham study in this issue has found young age at onset of Crohn's disease to be an independent factor for the relative risk of cancer - that is, compared with an age matched standard population. This finding is to be expected in view of the relative rarity of colorectal cancer among young people in the general population. There is as yet, however, no firm evidence of increased absolute risk for younger compared with older patients. In fact, many published studies, at least in ulcerative colitis, have found just the opposite. ${ }^{102526}$ In any event, the study from Birmingham may not be optimally suited to answer this question, since it did not include any cases of Crohn's disease with onset below age 15 .

Just as this important paper has shown us the similarity of cancer risks between ulcerative colitis and Crohn's colitis, many other studies have shown the similarity of the clinical and pathological features of the colorectal cancers that arise in the two diseases, including young age at occurrence of cancer, multiplicity of lesions, mucin abundance, association with strictures, and epithelial dysplasia and aneuploidy. ${ }^{27-38}$ It seems appropriate, therefore, that the Birmingham study should conclude by raising an issue adumbrated by Korelitz's group a decade ago $^{39}$ - the advisability of a surveillance programme for Crohn's colitis. The difficulty of the question is reflected in the self contradiction of the final two sentences of Gillen et al, which alternately refer to a surveillance policy as 'difficult to justify,' and then as 'sensible to consider'. ${ }^{13}$ Of course, the authors restrict the second recommendation to patients 'whose Crohn's disease started at a young age'. As we have discussed in the preceding paragraph, however, the absolute risk of cancer may be no lower and perhaps even higher in older patients.

The most rational position, therefore, in view of the equivalent risks, might be to adopt equivalent policies for the two diseases. In other words, debate the pros and cons of surveillance programmes to your heart's content ${ }^{40}$; but in the end, whatever you choose to do for your patients with ulcerative colitis, do no differently for those with Crohn's colitis of similar duration and extent.

Division of Gastroenterology,

D B SACHAR

Mount Sinai Medical Center,

One Gustave L Levy Place,

New York,

NY 10029-6574,

USA

1 Inflammatory Bowel Disease: From Bench to Bedside. Baltimore: Williams \& Wilkins, 1994: 349

2 Josh Billings (Henry Wheeler Shaw, American humorist), Encyclopedia of Wit and Wisdom, 1874.

3 Crohn BB, Rosenberg $\mathrm{H}$. Sigmoidoscopic picture of chronic ulcerative colitis. Am f Med Sci 1925; 170: 220-9.

4 Warren S, Sommers SC. Cicatrizing enteritis (regional enteritis) as a pathologic entity: analysis of one hundred and twenty cases. Am f Pathol 1948; 24: $475-501$.
5 Weedon DD, Shorter RG, Ilstrup DM, Huizenga KA, Taylor WR. Crohn's disease and cancer. N Engl f Med 1973; 289: 1099-102.

6 Gyde SN, Prior P, Macartney JG, Thompson H, Waterhouse JAH, Allan RN. Malignancy in Crohn's disease. Gut 1980; 21: 1024-9.

7 Shorter RG. Risk of intestinal cancer in Crohn's disease. Dis Colon Rectum 1983; 26: 686-90

8 Savoca PE, Ballantyne GH, Cahow CE. Gastrointestinal malignancies in Crohn's disease: a 20-year experience. Dis Colon Rectum 1990; 33: $7-11$

9 Korelitz BI. Carcinoma of the intestinal tract in Crohn's disease. Am F Gastroenterol 1983; 78: 44-6.

10 Greenstein AJ, Sachar DB, Smith H, Janowitz HD, Aufses AH Jr. Patterns of neoplasia in Crohn's disease and ulcerative colitis. Cancer 1980; 46: 405-7.

11 Greenstein AJ, Sachar DB, Smith H, Janowitz HD, Aufses AH Jr. A comparison of cancer risk in Crohn's disease and ulcerative colitis. Cancer 1981; 48: 2742-5.

12 Sachar DB. New concepts of cancer. Mt Sinai f Med 1983; 50: 133-7.

13 Gillen CD, Prior P, Andrews HA, Allan RN. Ulcerative colitis and Crohn's disease: a comparison of the colorectal cancer risk in extensive colitis. Gut 1994; 35: 1590-2.

14 Softley A, Clamp SE, Watkinson G, Bouchier IAD, Myren J, DeDombal FT. The natural history of inflammatory bowel disease: has there been a FT. The natural history of inflammatory bowel disease: has there been a
change in the last 20 years? Scand $f$ Gastroenterol 1988; 23 (Suppl 144): change in the last 20 years? Scand $\mathcal{F}$ Gastroenterol 1988; 23 (Suppl 144): 20-3.

15 Ekbom A, Helmick C, Zack M, Adami H-O. Increased risk of large-bowel cancer in Crohn's disease with colonic involvement. Lancet 1990; 336: $357-9$.

16 Gollop JH, Phillips SF, Melton LJ, Zinsmeister AR. Epidemiologic aspects of Crohn's disease: a population based study in Olmsted County, Minnesota, 1943-1982. Gut 1988; 29: 49-56.

17 Kvist N, Jacobsen O, Norgaard P, Ockelmann HH, Kvist HK, Schou G, et al. Malignancy in Crohn's disease. Scand f Gastroenterol 1986; 21: 82-6.

18 Fireman Z, Grossman A, Lilos P, Hacohen D, Bar Meir S. Intestinal cancer in patients with Crohn's disease. A population study in central Israel. in patients with Crohn's disease. A p

19 Munkholm P, Langholz E, Davidsen M, Binder V. Intestinal cancer risk and mortality in patients with Crohn's disease. Gastroenterology 1993; 105: mortality

20 Greenstein AJ, Sachar D, Pucillo A, Kreel I, Feller S, Janowitz HD, et al. Cancer in Crohn's disease after diversionary surgery: a report of seven carcinomas occurring in excluded bowel. Am $\mathcal{f}$ Surg 1978; 135: 86-90.

21 Senay E, Sachar DB, Keohane M, Greenstein AJ. Small bowel carcinoma in Crohn's disease: distinguishing features and risk factors. Cancer 1989; 63: 360-3.

22 Greenstein AJ, Meyers S, Szporn A, Slater G, Janowitz HD, Aufses AH Jr Colorectal cancer in regional ileitis. $O \mathcal{F} M e d$ 1987; 237: 33-40.

23 Cornes JS, Stecher M. Primary Crohn's disease of the colon and rectum. Gut 1961; 2: 189-201.

24 Lennard-Jones JE, Lockhart-Mummery HE, Morson BC, Stalder GA. Prognosis after resection of chronic regional ileitis. Gut 1967; 8: 332-6.

25 Ekbom A, Helmick C, Zack M, Adami $H-O$. Ulcerative colitis and colorectal cancer: a population-based study. $N$ Engl 7 Med 1990; 323: 1228-33.

26 Sugita A, Sachar DB, Bodian C, Ribeiro C, Aufses AH Jr, Greenstein AJ Colorectal cancer in ulcerative colitis: influence of anatomical extent and age at onset of colitis-cancer interval. Gut 1991; 32: 167-9.

27 Keighley MRB, Thompson H, Alexander-Williams J. Multifocal colonic carcinoma and Crohn's disease. Surgery 1975; 78: 534-7.

28 Hamilton SR. Colorectal carcinoma in patients with Crohn's disease. Gastroenterology 1985; 89: 398-407.

29 Petras RE, Mir-Madilessi SH, Farmer RG. Crohn's disease and intestinal carcinoma: a report of 11 cases with emphasis on associated epithelial dysplasia. Gastroenterology 1987; 93: 1307-14

30 Richards ME, Rickert RR, Nange FC. Crohn's disease-associated carcinoma: a poorly recognized complication of inflammatory bowel disease. Ann Surg 1989; 209: 764-73.

31 Yamazaki Y, Ribeiro MB, Sachar DB, Aufses AH Jr, Greenstein AJ. Malignant colorectal strictures in Crohn's disease. Am 7 Gastroenterol Malignant colorecta

32 Craft CF, Mendelsohn G, Cooper HS, Yardley JH. Colonic 'precancer' in Crohn's disease. Gastroenterology 1981; 80: 578-84.

33 Simpson S, Taube J, Riddel RH. The histologic appearance of dysplasia (precarcinomatous change) in Crohn's disease of the small and large intestine. Gastroenterology 1981; 81: 492-501.

34 Warren R, Barwick KW. Crohn's colitis with carcinoma and dysplasia Am f Surg Pathol 1983; 7: 151-9.

35 Korelitz BI, Lauwers GY, Sommers SC. Rectal mucosal dysplasia in Crohn's disease. Gut 1990; 31: 1382-6.

36 McKinley MJ, Budman DR, Kahn E. High grade dysplasia in Crohn's colitis characterized by flow cytometry. F Clin Gastroenterol 1987; 9: $452-5$.

37 Lofberg R, Brostrom O, Kartlé P, Ost A, Tribukait B. Carcinoma and DNA aneuploidy in Crohn's colitis: a histological and flow cytometric study. Gut 1991; 32: 900-4.

38 Choi PM, Zelig MP. Similarity of colorectal cancer in Crohn's disease and ulcerative colitis: implications for carcinogenesis and prevention. Gut 1994; 35: 950-4.

39 Cooper DJ, Weinstein MA, Korelitz B. Complications of Crohn's disease predisposing to dysplasia and cancer of the intestinal tract: considerations of a surveillance program. $\mathcal{F}$ Clin Gastroenterol 1984; 6: 217-24

40 Axon ATR. Cancer surveillance in ulcerative colitis - a time for reappraisal. Gut 1994; 35: 587-9. 